\title{
PENERAPAN PRINSIP YURISDIKSI IN REM (FORUM REI SITAE) DALAM GUGATAN ORANG TERKENAL TERHADAP CYBERSQUATTER DI INDONESIA
}

\author{
(THE APPLICATION OF THE PRINCIPLE OF JURISDICTION IN REM (THE FORUM REI SITAE) FAMOUS \\ PEOPLE IN A LAWSUIT AGAINST A CYBERSQUATTER IN INDONESIA)
}

\author{
Helitha Novianty Muchtar; Muhamad Amirulloh; dan Tasya Safiranita \\ Universitas Padjadjaran \\ Jl. Raya Bandung-Sumedang Km.21, Sumedang, Jawa Barat \\ Email: helitha.novianty@unpad.ac.id; muhamad.amirulloh@unpad.ac.id; tasya_safiranita@yahoo.com
}

Naskah diterima: 14 Juni 2018; revisi: 8 Agustus 2018; disetujui: 16 Agustus 2018

\begin{abstract}
Abstrak
Maraknya tindakan cybersquatting yang dilakukan oleh cybersquatter atas penggunaan nama domain terhadap suatu nama orang terkenal di dunia maya membuat gugatan pelanggaran nama domain semakin meningkat. Dalam beberapa kasus, penggunaan nama domain oleh cybersquatter merupakan kasus yang melintasi batas Negara yang di dalamnya terdapat unsur asing. Perwujudan dari yurisdiksi in rem melalui Forum Rei Sitae yakni penguasaan negara atas benda yang situsnya berada di wilayah teritorialnya. Dalam praktik peradilan di Indonesia, gugatan atas dasar kebendaan dalam hal ini nama domain yang terkait merek diajukan ke pengadilan dimana benda tersebut berada atau didaftarkan. Dalam penelitian ini hendak menjawab apakah penggunaan yurisdiksi in rem (forum rei sitae) ini dapat diterapkan pula pada kasus-kasus nama orang terkenal yang digunakan sebagai nama domain yang tempat dilakukannya pelanggaran/ sengketa berada di negara yang berbeda dan prinsip yurisdiksi manakah yang lebih efektif dalam penyelesaian sengketa nama orang terkenal yang digunakan sebagai nama domain di internet, metode pendekatan yang digunakan dalam penelitian ini adalah yuridis normatif, dengan spesifikasi penelitian deskriptif analitis. Hasil penelitian menyatakan bahwa penggunaan yurisdiksi in rem dapat digunakan dalam sengketa nama orang terkenal yang digunakan sebagai nama domain di internet, yurisdiksi in rem (forum rei sitae) juga dinilai lebih efektif dari sisi ekonomi dan penghentian pelanggaran penggunaan nama domain.
\end{abstract}

Kata Kunci: yurisdiksi in rem, nama domain, merek

\begin{abstract}
The rise of Cybersquatting action is done by the use of the cybersquatter domain name against a name famous people in cyberspace make the domain name infringement lawsuit increases, in some cases, the use of a domain name by cybersquatter is a case that crosses the boundaries of the country in which there is a foreign element. The embodiment of jurisdiction in the Forum Rei Sitae through brake is State mastery over the things that his site is in the territory. In judicial practice in Indonesia, the lawsuit by the material in this brand-related domain names submitted to the Court where the object is located or registered. In this research was about to answer whether the use of jurisdiction in rem (the forum rei sitae) this can be applied also in cases of famous person's name used as a domain name which is the place it does breach/ dispute in which different and the principle of jurisdiction which is more effective in resolving disputes of famous person's name used as a domain name on the internet, the method of the approach used in this study is the juridical normative, with specifications descriptive research analytical. Results of the study stated that the use of jurisdiction in rem could be used in a dispute over the name of a famous person is used as a domain name on the internet, jurisdiction in rem (the forum rei sitae) also rated more effective economically and termination violations of the use of the domain name.
\end{abstract}

Keywords: jurisdiction in rem, domain names, trademark 


\section{A. Pendahuluan}

Nama orang terkenal memiliki nilai ekonomis dan daya tarik yang kuat bagi pihak lain atau masyarakat untuk menggunakannya dalam media internet. Salah satu bentuk penggunaan nama orang terkenal di internet adalah nama domain. Nama domain merupakan sarana perdagangan secara elektronik (electronic commerce) sekaligus menjadi strategi bisnis era millennium, nama domain menjadi salah satu strategi bisnis era millenium yang paling jitu mengingat kemampuannya dalam promosi dan distribusi produk dapat menjangkau ke seluruh pelosok dunia dalam waktu yang sangat singkat. Pelanggaran kepemilikan nama domain akan mengakibatkan kerugian yang serius dalam aktivitas bisnis.

Nama orang terkenal mengandung makna tertentu tentang reputasi pribadi orang terkenal tersebut. Nama orang terkenal juga memiliki daya tarik yang kuat dan besar bagi pihak lain atau masyarakat terhadap informasi yang berkaitan dengan orang terkenal tersebut. Dalam hukum merek, orang terkenal juga mendapatkan perlindungan dari penggunaan dan/ atau pendaftaran namanya sebagai merek yang dilakukan pihak lain secara tanpa izin orang terkenal tersebut ${ }^{1}$.

Kasus penggunaan nama orang terkenal sebagai nama domain sudah banyak terjadi, misalnya kasus juliaroberts.com dan Steviewonder.com. ${ }^{2}$ Hal ini menimbulkan kerugian ekonomi bagi orang terkenal karena mereka menjadi tidak dapat menggunakan namanya sebagai nama domain dalam melakukan aktivitas di dunia maya (cyberspace), apalagi jika orang terkenal tersebut menggunakan namanya dalam kegiatan bisnis, hilangnya pendapatan yang seharusnya diperoleh, hilangnya potensi keuntungan, bahkan rusaknya reputasi orang terkenal tersebut. Dengan kata lain, orang terkenal tersebut menjadi kehilangan hak eksklusif dan kesempatan dalam berbisnis di internet, padahal internet dengan e-commerce juga dapat menjadi tempat untuk melakukan kegiatan perdagangan barang dan/ atau jasa. ${ }^{3}$

Pendaftaran nama domain di PANDI terus meningkat untuk setiap tahunnya, data statistik diambil oleh pandi dari Januari 2016 hingga bulan April 2018 dari data statistik tersebut didapat peningkatan pendaftaran nama domain di bulan Maret 2017 sebanyak 250.000 pendaftar dan bulan November tahun 2017 sebanyak 260.000 pendaftar, sedangkan pendaftaran nama domain paling rendah terjadi di bulan Januari 2016 sebanyak 160.000 pendaftar, pada periode Januari hingga Mei 2016 dan bulan Februari hingga April 2018 terjadi kestabilan jumlah pendaftaran ${ }^{4}$.

Maraknya kasus penggunaan nama orang terkenal sebagai nama domain secara tidak sah

Muhamad Amirulloh, "Penggunaan Nama Kota Sebagai Nama Domain di Indonesia", Sosiohumaniora 19:1, (2017): 13.

2 WIPO Arbitration and Mediation Center, "Administrative Panel Decision: Julia Viona Robert v Russel Boyd Case No.D2000-0210, 2000, http://www.wipo.int/amc/en/domains/decisions/html/2000/d2000-0210.html, (diakses 28 mei 2018) lihat juga The Hon Neil Brown QC, " the Arbitration of Celebrity Domain Name Dispute", 2008, https://udrp.adr.eu/_inc/en/resource/arbitration_platform/article_en_1.pdf, (diakses 28 Mei 2018)

3 Muhamad Amirulloh, Rika Ratna Permata,dan helitha Novianty, Kewenangan Orang Terkenal dalam Menggugat Cybersquater berdasarkan Undang-Undang Nomor 11 Tahun 2008 Tentang Informasi dan Transaksi Elektronik dan Undang-Undang Nomor 20 Tahun 2006 Tentang Merek di Indonesia, (Laporan Akhir Penelitian Unggulan Perguruan Tinggi, Agustus 2017), hlm.12.

4 Pengelola Nama Domain Internet Indonesia, "Statistic Domain 2016-2018", https://pandi.id/en/statistic/, (diakses 15 Juni 2018). 
di internet menjadi salah satu tantangan bagi dunia hukum siber, hukum kekayaan intelektual dan hukum perdata internasional, dalam hukum perdata internasional sengketa penggunaan nama orang terkenal sebagai nama domain merupakan sengketa yang yang terdapat unsur asing di dalamnya dan melintasi batas Negara, dilihat dari sisi hukum perdata internasional, titik taut primer sebagai titik taut penentu apakah satu kasus merupakan hukum perdata internasional atau bukan telah terpenuhi yaitu adanya unsur asing dalam suatu kasus hukum perdata.

Hukum Perdata Internasional adalah keseluruhan asas dan kaidah yang menunjukkan stelsel hukum mana yang berlaku dalam suatu perkara hukum perdata yang di dalamnya terdapat unsur asing 5 . Dalam hukum perdata internasional terdapat titik pertalian yaitu titik pertalian primer, titik taut sekunder dan titik taut lanjutan. Titik taut primer adalah keadaankeadaan atau hal-hal yang menciptakan atau menjadikan satu perkara memiliki hubungan perdata internasional, titik taut primer dikenal sebagai unsur asing yang ada dalam suatu perkara, terdapat enam macam titik taut primer yaitu kewarganegaraan, bendera kapal, domisili, tempat kediaman, tempat kedudukan dan pilihan hukum. ${ }^{6}$

Letaknya suatu benda (situs) merupakan titik taut yang menentukan hukum yang harus diberlakukan (lex rei Sitae) baik benda tetap atau benda bergerak diberlakukan lex rei sitae tetapi penggunaan lex rei sitae adalah penggunaan hukum dalam suatu perkara, sebelum menentukan hukum yang berlaku maka haruslah ditentukan lebih dulu forum pengadilan mana yang berwenang mengadili (yurisdiksi) dalam suatu perkara khususnya perkara nama domain.

Hukum perdata internasional mengenal tentang yurisdiksi (kewenangan mengadili) dari suatu pengadilan, setiap Negara mempunyai yurisdiksi eksklusif dalam suatu sengketa yang berada di dalam wilayahnya. ${ }^{7}$ Yurisdiksi eksklusif ini disebabkan karena pelindungan atas nama domain yang terkait kekayaan intelektual pelindungan bersifat territorial. ${ }^{8}$

Berdasarkan latar belakang tersebut dapat diambil dua permasalahan, pertama apakah yurisdiksi in rem (forum rei sitae) dapat diterapkan pada gugatan nama orang terkenal yang digunakan sebagai nama domain yang tempat dilakukannya pelanggaran/ sengketa berada di Negara yang berbeda? Prinsip yurisdiksi manakah yang lebih efektif dalam penyelesaian sengketa nama orang terkenal yang digunakan sebagai nama domain di internet?

Merujuk pada permasalahan yang akan diangkat, tujuan diadakannya penelitian ini adalah untuk mengetahui sejauh mana keefektifan penerapan yurisdiksi In Rem (forum Rei sitae) dalam menyelesaikan sengketa-

Sudargo Gautama, Pengantar Hukum Perdata Internasional, (Bandung: Bina Cipta, 1987), hlm. 4.

6 Naskah Akademik RUU tentang Hukum Perdata Internasional, (Badan Pembinaan Hukum Nasional Kementerian Hukum dan Hak Asasi Manusia, November 2014), hlm.11.

7 Pedro Alberto De Miguel Asensio, The Private International Law Of Intellectual Property And Of Unfair Commercial Practices: Convergence Or Divergence? S. Leible and A. Ohly (eds.), Intellectual Property and Private International Law, (Tübingen:Mohr Siebeck,2009), hlm.6.

8 Van Eechoud, The defendant usually resides in the same state in which it carries out its activities and is often the only state with jurisdiction di dalam Lydia Lundstedt, Territoriality in intellectual property law, Stockholm University (Stockholm:Sweden by Holmbergs,2003), hlm. 33. 
sengketa di nama domain terkait merek di Indonesia, dan untuk mengetahui prinsip yurisdiksi manakah yang paling tepat dan sesuai dalam penyelesaian sengketa nama domain terkait merek.

\section{B. Metode penelitian}

Metode pendekatan yang digunakan dalam penelitian ini adalah yuridis normatif yang menitikberatkan penelitian pada ketentuan hukum yang berlaku dan prinsip serta asas yang digunakan dalam Hukum Perdata Internasional.

Spesifikasi penelitian ini adalah deskriptif analitis, yaitu dengan memberikan fakta-fakta penggunaan nama orang terkenal sebagai nama domain, serta efektifitas penggunaan yurisdiksi In Rem (forum rei sitae) dalam kasus penggunaan nama orang terkenal sebagai nama domain berdasarkan ketentuan UU ITE, UU Merek, prinsip Hukum Perdata Internasional yang dapat dijadikan sebagai dasar hukum gugatan ganti rugi.

Tahap penelitian ini meliputi penelitian dengan studi kepustakaan. Penelitian kepustakaan dilakukan untuk memperoleh bahan hukum primer berupa bahan hukum yang mengikat seperti peraturan perundangundangan nasional dan instrumen hukum internasional sebagaimana tersebut dalam metode pendekatan, dan bahan hukum tersier yang berupa ensiklopedia dan berbagai artikel di media cetak dan elektronik.
Teknik pengumpulan data yang digunakan adalah studi dokumen yang dilakukan terhadap data sekunder untuk mendapatkan landasan teoritis, pendapat-pendapat atau tulisan-tulisan para ahli atau pihak lain berupa informasi baik dalam bentuk formal maupun data melalui naskah resmi.

Terhadap data yang telah dikumpulkan, baik data sekunder sebagai hasil studi kepustakaan maupun data primer sebagai hasil studi lapangan, dianalisis secara kualitatif dengan pendekatan abstrak-teoretis. ${ }^{9}$ Pendekatan abstrak-teoritis mempunyai arti penting dalam penelitian hukum normatif, mengingat hukum memiliki struktur logika yang sangat kuat. ${ }^{10}$ Terdapat relasi yang erat antara hukum dan logika, bahkan sifat logis merupakan sifat khusus dari hukum. ${ }^{11}$ Hasil analisis ini kemudian dipaparkan dalam bentuk deskriptif. Data yang bersifat kuantitatif sepanjang diperlukan akan disajikan dalam bentuk tabel-tabel dengan maksud untuk memudahkan pemahaman dan analisis.

Data sekunder dalam bentuk bahan hukum primer berupa peraturan perundang-undangan dan kebijakan pemerintah sebagaimana telah dikemukakan dalam bagian pendekatan dan bahan penelitian, dianalisis dengan menggunakan metode-metode penafsiran hukum seperti penafsiran historis, penafsiran sistematis (logis), penafsiran sosiologis, dan penafsiran futuristis. ${ }^{12}$

$9 \quad$ Maria S.W. Sumardjono, "Pedoman Pembuatan Usulan Penelitian" (makalah disampaikan pada Seminar tentang Metodologi Penelitian bagi Dosen Fakultas Hukum Universitas Gadjah Mada, Yogyakarta,12 April 1989).

10 Paul Scholten diterjemahkan oleh B. Arief Sidharta, Struktur Ilmu Hukum (De Structuur der Rechtswetenschap) (Bandung: Alumni, cetakan pertama, 2003), hlm. 25.

11 Hans Kelsen diterjemahkan oleh B. Arief Sidharta, Hukum dan Logika (Essays in Legal and Moral Philosophy), (Bandung: Alumni, cetakan kedua, 2002), hlm. 27.

12 Sudikno Mertokusumo, Penemuan Hukum: Sebuah Pengantar, (Yogyakarta: Liberty, edisi pertama, 1996), hlm. 57-61. 
Metode penafsiran historis dipergunakan untuk mengetahui latar belakang dan sejarah pembentukan peraturan perundang-undangan dan kebijakan dalam hal pemilikan dan penggunaan nama orang terkenal sebagai nama domain. Penafsiran sistematis digunakan mengingat banyaknya peraturan dan kebijakan yang mengatur pemilikan merek, penggunaan dan pemanfaatan nama orang terkenal sebagai nama domain. Metode penafsiran sosiologis diperlukan mengingat penerapan prinsipprinsip hukum acara perdata dan merek serta hukum teknologi informasi dan komunikasi dalam perlindungan hukum (acara) terhadap penggunaan nama orang terkenal sebagai nama domain, sehingga diperlukan pemahaman yang baik, mengenai nilai-nilai keadilan, demokrasi, perlindungan dan penegakkan hukum dalam arti yang sebenar-benarnya di masyarakat.

Data sekunder dalam bentuk bahan hukum tersier yang berupa kamus hukum, biografi dan indeksasi peraturan perundang-undangan dan di lapangan kebijakan hukum merek dan hukum teknologi informasi dan komunikasi dianalisis untuk mempermudah dan memperjelas pemahaman atas bahan hukum primer dan bahan hukum sekunder, sehingga diperoleh pemahaman yang integral-komprehensif atas data sekunder tersebut.

\section{Pembahasan}

1. Penerapan Yurisdiksi In rem (Forum Rei Sitae) pada sengketa penggunaan nama orang terkenal sebagai nama domain.

Nama domain (domain name) dalam terminologi yuridis dapat diartikan sebagai jati diri yang digunakan sebagai identitas seseorang, perusahaan, atau badan hukum lainnya agar dapat berkomunikasi di cyberspace. Nama domain ini bisa merupakan nama perseorangan, nama perusahaan, atau bahkan nama produk tertentu ${ }^{13}$.

Nama domain itu sendiri dapat berupa nama, susunan huruf, kata, atau angka. Pembacaan domain name dilakukan dari kanan ke kiri yang menunjukkan tingkat spesifikasinya, dari yang paling umum ke yang paling khusus. Salah satu contoh bandung.go.id, "id" menunjuk kepada Indonesia sebagai wilayah geografis (geographical region), sedangkan "go" artinya pemerintah (government) sebagai TopLevel Domain Name (TLD) yang menjelaskan mengenai tujuan dari institusi tersebut. Elemen selanjutnya adalah "bandung" yang merupakan "The Second-Level Domain Name (SLD)" yang dipilih oleh pendaftar domain name ${ }^{14}$.

Dalam beberapa kasus nama domain seperti kasus juliaroberts.com dan Steviewonder. com menimbulkan kerugian ekonomi yang cukup besar bagi orang terkenal karena orang terkenal tidak bisa menggunakan namanya sebagai nama domain dalam melakukan aktivitas di dunia maya (cyberspace) khususnya dalam kegiatan bisnis ${ }^{15}$, dengan digunakannya

Mieke Komar Kantaatmadja et.al, Cyberlaw - Suatu Pengantar, (Jakarta: ELIPS II, 2002), hlm 110.

14 Muhamad Djumhana, Perkembangan Doktrin dan Teori Perlindungan Hak Kekayaan Intelektual, (Bandung: PT. Citra Aditya Bakti, 2006), hlm. 84.

15 Deborah E. Bouchoux, Intellectual Property (the law of trademarks, Copyrights, Patents and Trade Secrets, (New York: Delmar Cengage Learning 5 Maxwell Drive,2012), hlm.147 
nama orang terkenal sebagai nama domain maka hilang pula pendapatan yang harusnya diperoleh oleh orang terkenal, hilangnya potensi keuntungan, bahkan rusaknya reputasi orang terkenal tersebut. Dengan kata lain, orang terkenal tersebut menjadi kehilangan hak eksklusif dan kesempatan dalam berbisnis di internet, padahal internet dengan e-commerce juga dapat menjadi tempat untuk melakukan kegiatan perdagangan barang dan/ atau jasa.

Kasus penggunaan nama orang terkenal yang terjadi di Indonesia salah satunya adalah penggunaan nama domain "cak nun" atau "Emha Ainun Nadjib" sebagai nama domain dalam akun facebook, twitter dan youtube. ${ }^{16}$ Penggunaan nama orang terkenal sebagai nama domain merupakan tindakan yang melawan hukum, karena di dalamnya menimbulkan kerugian baik materiil ataupun imateriil.

Instrumen hukum (internasional) terkait kepemilikan nama domain Uniform Domain Name Dispute Resolution Policy (UDRP) sebagai memiliki ruang lingkup yang sangat terbatas, yaitu pada upaya pemindahan, perubahan atau penghapusan nama domain. Adanya fakta bahwa ada kerugian ekonomis akibat penggunaan merek sebagai nama domain oleh pihak lain secara tanpa hak, membuat para pemilik merek yang haknya dilanggar mencoba mencari dasar hukum untuk melakukan gugatan ganti rugi perdata ${ }^{17}$.

Dalam kasus penggunaan nama orang terkenal sebagai nama domain pada awalnya merupakan kasus perbuatan melawan hukum, karena penggunaan nama secara tanpa hak merupakan pelanggaran terhadap Pasal 1365 Kitab Undang-Undang Hukum Perdata (KUHPerdata), dalam Pasal 1365 dinyatakan bahwa:

Perbuatan melawan hukum diatur dalam Pasal 1365 KUHPerdata, berbunyi: "Tiap perbuatan yang melanggar hukum dan membawa kerugian kepada orang lain, mewajibkan orang yang menimbulkan kerugian itu karena kesalahannya untuk menggantikan kerugian tersebut."

Dari bunyi Pasal tersebut, maka dapat ditarik unsur-unsur Perbuatan Melawan Hukum (PMH) sebagai berikut ${ }^{18}$ : (1) ada perbuatan melawan hukum; (2) ada kesalahan; (3) ada hubungan sebab akibat antara kerugian dan perbuatan; (4) ada kerugian.

Meskipun pada awalnya Praktik penggunaan nama orang terkenal sebagai nama domain ini adalah perbuatan melawan hukum, tetapi di dalamnya terdapat hak, khususnya hak kebendaan yang harus dipertahankan.

Tuntutan hak adalah bertujuan untuk memperoleh perlindungan hak yang diberikan oleh pengadilan. Pihak yang mengajukan tuntutan hak memerlukan atau berkepentingan akan perlindungan hukum. Sudah selayaknya apabila disyaratkan harus adanya kepentingan untuk mengajukan tuntutan hak. Pihak yang tidak menderita kerugian tidak memiliki kepentingan sehingga sewajarnya tidak dapat diterima, akan tetapi tidak setiap kepentingan dapat diterima sebagai dasar pengajuan gugatan. Hanya kepentingan yang cukup dan

16 Lihat Toto Raharjo, "Penyalahgunaan Nama Cak Nun untuk Akun Media Sosial Tidaklah BertanggungJawab", 28 Desember 2015, https://www.caknun.com/2015/menyalahgunakan-nama-cak-nun-untuk-akun-media-sosialtidaklah-bertanggungjawab/ (diakses 15 Juni 2018).

17 Subekti, Pokok-Pokok Hukum Perdata (Jakarta:Intermasa,2001), hlm.133.

18 Ibid. 
layak serta mempunyai dasar hukum sajalah yang data diterima sebagai dasar tuntutan hak ${ }^{19}$.

Perlindungan hak kebendaan terhadap orang terkenal juga telah diatur dengan pendaftaran nama orang terkenal tersebut sebagai merek berdasarkan Pasal 21 ayat (2) huruf a UU Merek dan Indikasi Geografis. Pada asasnya, setiap orang yang merasa mempunyai hak atau menuntutnya atau ingin mempertahankan atau membelanya, berwenang untuk bertindak selaku pihak, baik sebagai penggugat maupun sebagai tergugat (legitima persona stands in

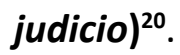

Kemampuan untuk bertindak (handelingsbekwaamheid) sebagai pihak itu merupakan komplemen yang penting daripada kewenangan hukum (rechtsbevoegdheid) atau kewenangan untuk menjadi pendukung hak. Siapa yang dianggap tidak mampu untuk bertindak (personae miserabiles) dianggap tidak mampu pula untuk bertindak selaku pihak di muka pengadilan. ${ }^{21}$ Terkait asas ini, baik orang terkenal yang namanya digunakan sebagai nama domain internet, maupun pelaku (cybersquatter) yang mendaftarkan dan/atau menggunakan nama orang terkenal sebagai nama domain internet, merupakan pihak yang dapat/ mampu menjadi para pihak dalam persengketaan di muka pengadilan di Indonesia 22 .

Orang terkenal dapat menjadi pihak yang menuntut atau mempertahankan atau membela haknya, baik haknya sebagai orang terkenal karena hak perseorangan atas namanya maupun haknya sebagai orang terkenal karena hak kebendaan atas mereknya yang berupa namanya. Hal ini juga sejalan dengan asas point $d^{\prime}$ interest, point $d^{\prime}$ ' action. ${ }^{23}$

Pihak pelaku (cybersquatter) dapat menjadi pihak yang dituntut atau digugat karena tanpa ijin/ melanggar hak orang terkenal dengan mendaftarkan/ menggunakan nama orang terkenal/ merek berupa nama orang terkenal sebagai nama domain internet.

Penggunaan nama orang terkenal yang belum didaftarkan sebagai merek di Indonesia akan marak terjadi, seperti penggunaan nama Emha Ainun Najib, Gusdur.com, dan penggunaan nama orang terkenal lainnya, penggunaan nama secara tanpa hak. Progress dan Redaktur Maiyah selaku afiliasi pengelola akun media sosial resmi Emha Ainun Nadjib (Cak Nun), telah berdiskusi bersama Cak Nun seputar media sosial. Hal tersebut dilakukan sehubungan dengan adanya nama Cak Nun atau Emha Ainun Nadjib yang banyak dipakai sebagai nama akun oleh orang lain, baik di Facebook, Twitter, Youtube, dan lain-lain.

Selain digunakannya nama Cak Nun untuk akun secara tidak bertanggung jawab itu, kita juga menemukan tayangan-tayangan khususnya di Youtube yang memuat potongan-potongan kalimat Cak Nun yang sebagai akibatnya dapat menimbulkan bias dan lepas konteks, misalnya potongan yang dihadirkan untuk mengadu domba atau memversuskan pendapat Cak Nun dengan pendapat orang lain.

19 Retnowulan Sutantio dan Iskandar Oeripkartawinata, Hukum Acara Perdata dalam Teori dan Praktek, (Bandung: Mandar Maju Cetakan VIII, 1997), hlm.3.

20 Sudikno Mertokusumo, Hukum Acara Perdata Indonesia, (Yogyakarta: Penerbit Liberty Cetakan Pertama, Edisi Kelima, 1998), hlm.53.

21 Ibid.

22 Ibid.

23 Ibid, hlm.51 
Beberapa kasus penggunaan nama orang terkenal sebagai nama domain bisa dilakukan melintasi batas negara, dalam hal nama domain didaftarkan di tempat yang berbeda (negara yang berbeda) maka objek sengketa berupa benda (nama domain) berada di wilayah negara lain, dengan adanya unsur asing berupa letak benda maka kasus nama domain merupakan kasus hukum perdata international (HPI).

Dalam ranah Hukum Perdata Internasional (HPI) hal yang paling utama yang dipertanyakan adalah gugatan diajukan dimana atau dalam yurisdiksi manakah kasus tersebut berada, penentuan dasar yurisdiksi suatu pengadilan dalam lapangan Hukum Perdata Internasional dibagi menjadi 2 besar yaitu yurisdiksi in personam dan Yurisdiksi in rem. ${ }^{24}$

Gugatan dibedakan menjadi tiga macam, yaitu persoonlijke rechtsvordering (gugatan yang bersifat perorangan), zakelijke rechtsvordering (gugatan yang bersifat kebendaan) dan gemengde rechtsvordering (gugatan yang bersifat campuran) hal ini dinyatakan pada Pasal 102 Rv.

Gugatan perorangan didasarkan atas suatu perikatan baik perikatan yang bersumber dari penjanjian maupun perikatan yang timbul dari peraturan perundang-undangan. Gugatan perorangan ditujukan untuk memintan pertanggungjawaban dari seseorang sehingga gugatannya bersifat mengadili segala perbuatan yang dilakukan oleh tergugat. Dengan demikian gugatan yang bersifat perorangan ini diajukan ke pengadilan yang memiliki yurisdiksi in personam atas diri tergugat ${ }^{25}$. Lain hal nya dengan gugatan perorangan, gugatan kebendaan adalah gugatan yang menuntut penyerahannya suatu barang, gugatan kebendaan hanya menegaskan dan mengembalikan hak seseorang atas suatu kebendaan. Sehingga gugatan yang bersifat kebendaan ini seharusnya diajukan kepada pengadilan yang memiliki yurisdiksi in rem atas kebendaan tersebut.

Di beberapa Negara Forum Rei Sitae ${ }^{26}$ dilakukan secara luas tidak hanya digunakan untuk benda-benda yang secara langsung terkait dengan perkara saja, tetapi juga kewenangan pengadilan timbul karena penggugat menuntut agar kekayaan milik tergugat yang terdapat di wilayah hukum pengadilan tersebut dilekatkan pada quasi in rem (meskipun tidak ada kaitan langsung antara kekayaan dan pokok perkara) ${ }^{27}$. Di beberapa Negara khususnya Negara Amerika Serikat quasi in rem tidak diterapkan hanya terbatas pada banda tetap saja tetapi juga benda bergerak dan intangible asset di dalamnya seperti hak kekayaan intelektual, saham dan aset tidak berwujud lainnya. ${ }^{28}$

Kasus nama domain pada dasarnya adalah kasus perbuatan melawan hukum hanya yang ditekankan adalah upaya untuk meminimalisir kerugian yang diderita oleh penggugat (orang terkenal) dengan cara menuntut dicabutnya hak kebendaan dari tergugat oleh karena itu

24 Bayu Seto Hardjowahono, Dasar-Dasar Hukum Perdata Internasional (Bandung: Citra Aditya Bakti,2006), hlm.168.

25 Wirjono Prodjodikoro, Perbuatan Melanggar Hukum Dipandang Dari Sudut Hukum Perdata (Bandung: Mandar Maju, 2000), hlm. 10.

26 Ilhami Ginang Pratinida," Penerapan Forum Rei Sitae", yuridika Jurnal,Vol 30, (2015), https://e-journal.unair. ac.id/index.php/YDK/index (diakses 15 Juni 2018).

27 Trevor C. Hartley, International Commercial Litigation (Text, Cases and Materials on Private International Law (United Kingdom: Cambridge University Press, 2010), hlm. 12.

28 Arthur T. Von Mehren, Adjudicatory Authority in Private International Law: A Comparative Study (Dordrecht Netherlands: Martinus Nijho Publishers ed, 2007), hlm. 23. 
untuk kasus nama domain Forum Rei Sitae lebih diperlukan.

Prinsip-prinsip hukum kebendaan harus pula ditelaah dan diterapkan mengingat nama orang terkenal yang semula termasuk dalam hak-hak perorangan, telah berkembang menjadi hak kebendaan dengan praktik penggunaan nama orang terkenal tersebut sebagai nama domain internet. Hal ini menyebabkan penggunaan tersebut mencakup pula aspek hukum bisnis, karena dalam perkembangannya nama orang terkenal tersebut telah menjelma menjadi aset bisnis dalam perdagangan secara elektronik (Electronic commerce). ${ }^{29}$

Berdasarkan pengertian hukum perdata, perbuatan penggunaan nama orang terkenal sebagai nama domain merupakan perbuatan yang termasuk dalam ruang lingkup hukum perdata. Hal ini mengingat perbuatan tersebut menyangkut kepentingan antar warga negara perseorangan yang satu dengan warga negara perseorangan yang lain, yaitu antara orang terkenal yang namanya digunakan sebagai nama domain dengan orang lain yang menggunakan nama orang terkenal sebagai nama domain secara tanpa hak (cybersquatter). Praktik cybersquatting merupakan bentuk baru perbuatan hukum yang lahir dalam masyarakat sebagai akibat perkembangan teknologi informasi dan komunikasi.

Hukum Benda dan Hukum Perikatan merupakan bagian dari Hukum Harta Kekayaan. Hukum harta kekayaan adalah peraturanperaturan hukum yang mengatur tentang hak dan kewajiban manusia yang bernilai uang. Hak dan kewajiban itu timbul karena adanya hubungan antara subjek hukum yang satu dengan yang lainnya hukum harta kekayaan meliputi dua lapangan, yaitu:

a) Hukum benda yang berupa peraturanperaturan yang mengatur hak-hak kebendaan yang mutlak sifatnya artinya bahwa atas hak-hak benda itu orang wajib menghormatinya.

b) Hukum perikatan peraturan-peraturan yang mengatur hubungan hukum yang bersifat kehartaan antara dua orang atau lebih dimana pihak yang satu berhak atas suatu prestasi tertentu sedangkan pihak yang lain wajib memenuhi prestasi. Contoh prestasi jual beli rumah.

Praktik penggunaan nama orang terkenal sebagai nama domain, dapat dikategorikan sebagai bidang hukum perdata yang terkait dengan perikatan yang diatur dalam Buku II, dan kebendaan (atau kekayaan) yang diatur dalam Buku III Kitab Undang- undang Hukum Perdata.

Nama Domain dapat dikategorikan sebagai benda karena pada prinsipnya Benda adalah segala sesuatu yang dapat menjadi objek hukum. Benda menurut KUHPerdata Pasal 499 adalah segala barang dan hak yang dapat dipakai orang (menjadi objek hak milik).

Penguasaan atas hak kebendaan akan menimbulkan kerugian baik secara materiil maupun immaterial, Pengertian kerugian menurut R. Setiawan, adalah kerugian nyata yang terjadi karena wanprestasi. Adapun besarnya kerugian ditentukan dengan membandingkan keadaan kekayaan setelah wanprestasi dengan keadaan jika sekiranya

29 Wirjono Prodjodikoro, Asas-Asas Hukum Perjanjian, (Bandung: Sumur, 1993), hlm. 13-14., dalam Rachmadi Usman, Hukum Hak Atas Kekayaan Intelektual, Perlindungan dan Dimensi Hukumnya di Indonesia, (Bandung: PT. Alumni, 2003), hlm. 77. 
tidak terjadi wanprestasi. ${ }^{30}$ Pengertian kerugian yang hampir sama dikemukakan pula oleh Yahya Harahap, ganti rugi ialah "kerugian nyata" atau "fietelijke nadeel" yang ditimbulkan perbuatan wanprestasi. ${ }^{31}$ Kerugian nyata ini ditentukan oleh suatu perbandingan keadaan yang tidak dilakukan oleh pihak debitur.

Nama domain sebagai bentuk hak kebendaan dari perorangan, dalam hal terjadi pelanggaran dan penggunaan tanpa izin dapat menggunakan gugat ganti kerugian sebagai wujud penegakan hak perorangan. Pada prinsipnya nama domain yang merupakan hak kebandaan dari perorangan dapat dianalogikan sebagai harta kekayaan seseorang yang bernilai materiil, dan pelanggaran terhadapnya dapat digugat ganti kerugian, baik materiil maupun immateriil.

Bentuk-bentuk kerugian dapat kita bedakan atas dua bentuk yakni: Kerugian materiil; dan Kerugian immateriil undang-undang hanya mengatur penggantian kerugian yang bersifat materiil.

Kemungkinan terjadi bahwa kerugian itu menimbulkan kerugian yang immateriil, tidak berwujud, moril, idiil, tidak dapat dinilai dengan uang, tidak ekonomis, yaitu berupa sakitnya badan, penderitaan batin, rasa takut, dan sebagainya.

Dalam kasus nama domain, hal yang paling utama adalah menutup atau membatalkan penggunaan nama orang terkenal sebagai nama domain, dalam hal ini terkait penutupan nama domain dan gugatan diajukan dimana nama domain didaftarkan oleh karena itu penggunaan yurisdiksi yang tepat untuk penggunaan nama orang terkenal sebagai nama domain adalah
Forum Rei Sitae, Forum rei sitae adalah bentuk dari Yurisdiksi In Rem atau Quasi In Rem yaitu yurisdiksi atas benda-benda bukan terhadap seseorang (person). Dalam Yurisdiksi In Rem putusan tidak memaksa atau menghukum seseorang melakukan suatu tindakan karena yang diadili bukan orangnya tetapi ditujukan untuk menegaskan dan mengembalikan kepemilikan atas benda kepada pihak yang berhak.

Pasal 118 ayat 3 HIR mengatur tentang prinsip Forum Sitae di Indonesia, dalam Pasal tersebut dinyatakan "apabila tempat diam dari tergugat tidak dikenal, lagi pula tempat tinggal sebetulnya tidak diketahui, atau jika tergugat tidak dikenal atau jika surat gugat itu tentang barang gelap. Maka surat gugat itu dimasukkan kepada ketua pengadilan negeri di daerah hukum siapa terletak barang itu. Beranjak dari ketentuan tersebut dapat diartikan jika terdapat perkara perbuatan melawan hukum di Indonesia dapat diajukan ke pengadilan yang wilayah hukumnya merupakan wilayah hukum dimana tempat yang disengketakan berada.

Apabila penggugat memilih untuk mengajukan gugatan berdasarkan perbuatan melanggar hukum, maka forum rei sitae tidak dapat dilaksanakan, karena terhadap gugatan yang bersifat perorangan berlaku yurisdiksi in personam yang titik tautnya berasal dari keberadaan tergugat. Sedangkan, apabila penggugat memilih untuk mengajukan gugatan yang bersifat kebendaan, maka forum rei sitae dapat dilaksanakan. Akan tetapi, kelemahan dari gugatan yang bersifat kebendaan adalah gugatan ini hanya ditujukan untuk revindicatoir (mengembalikan) benda-benda yang dikuasi 
oleh orang yang tidak berhak, sehingga penggugat tidak dapat menuntut ganti kerugian. Sedangkan dalam gugatan berdasarkan perbuatan melanggar hukum, dimungkinkan adanya pengembalian hak, sekaligus pemberian ganti kerugian baik materiil maupun immateriil. Atas dasar hal tersebut, umumnya penggugat lebih memilih untuk mengajukan gugatan berdasarkan perbuatan melanggar hukum, dengan menarik gugatan yang bersifat kebendaan ke dalam gugatan berdasarkan perbuatan melanggar hukum.

Dalam kasus penggunaan nama orang terkenal sebagai nama domain hal yang paling utama adalah pengembalian hak dan pemulihan kerugian atau menutup kerugian akibat peggunaan hak kebendaan secara tidak sah yang dilakukan oleh tergugat, penutupan kerugian dan pemulihan kerugian ini dilakukan dengan pengembalian (revindicatoir) bendabenda bergerak (nama domain) yang dikuasai oleh tergugat kepada yang berhak, sekaligus pemberian ganti kerugian baik materiil maupun immateriil. Atas dasar hal tersebut, mengajukan gugatan kebendaan untuk mempercepat pemulihan kerugian dan penutupan kerugian yang akan terus berlangsung. Diperlukan adanya forum yang tepat dan cepat terkait dengan pemulihan kerugian dan penghentian kerugian, memalui forum rei sitae diharapkan hakim akan memutus perkara kebendaan terlebih dahulu agar menekan kerugian yang lebih besar lagi.

\section{Efektifitas Yurisdiksi In Rem untuk sengketa penggunaan nama orang terkenal sebagai nama domain}

Yurisdiksi dalam hukum perdata internasional dapat diartikan forum yang berwenang untuk mengadili dan memutuskan suatu persoalan hukum yang diajukan.
Secara umum, untuk gugatan perdata, pengajuan gugatan didasarkan pada asas Actor Sequitur Forum Rei. Asas tersebut diatur dalam Pasal 118 ayat (1) Herzien Inlandsch Reglement ("HIR") yang menentukan bahwa yang berwenang mengadili suatu perkara adalah Pengadilan Negeri tempat tinggal tergugat. Namun, penerapan asas tersebut tidaklah mutlak, lebih jauh diuraikan oleh M. Yahya Harahap dalam bukunya, Hukum Acara Perdata (hal. 192-202), setidaknya ada 7 patokan dalam menentukan kewenangan relatif pengadilan berdasarkan Pasal 118 HIR/ Pasal 142 RBg, yakni:

1) Actor Sequitur Forum Rei (gugatan diajukan ke Pengadilan Negeri pada tempat tinggal tergugat);

2) Actor Sequitur Forum Rei dengan Hak Opsi (dalam hal ada beberapa orang tergugat, gugatan diajukan ke Pengadilan Negeri pada tempat tinggal salah satu tergugat atas pilihan penggugat);

3) Actor Sequitur Forum Rei Tanpa Hak Opsi, tetapi berdasarkan tempat tinggal debitur principal (dalam hal para tergugat salah satunya merupakan debitur pokok/debitur principal, sedangkan yang selebihnya berkedudukan sebagai penjamin, maka gugatan diajukan ke Pengadilan Negeri pada tempat tinggal debitur pokok/principal);

4) Pengadilan Negeri di Daerah Hukum Tempat Tinggal Penggugat (dalam hal tempat tinggal atau kediaman tergugat tidak diketahui);

5) Forum Rei Sitae (Gugatan diajukan ke Pengadilan Negeri berdasarkan patokan tempat terletak benda tidak bergerak yang menjadi objek sengketa);

6) Kompetensi Relatif Berdasarkan Pemilihan Domisili (para pihak dalam perjanjian dapat menyepakati domisili pilihan yakni menyepakati untuk memilih Pengadilan 
Negeri tertentu yang akan berwenang menyelesaikan sengketa yang timbul dari perjanjian);

7) Negara atau Pemerintah dapat digugat pada setiap Pengadilan Negeri (dalam hal Pemerintah Indonesia bertindak sebagai penggugat atau tergugat mewakili negara, gugatan dapat diajukan ke Pengadilan Negeri di mana departemen yang bersangkutan berada).

Yurisdiksi in Rem adalah Yuridiksi atas benda yang berada di dalam wilayah negara forum, yang secara langsung maupun tidak langsung berkaitan dengan perkara yang sedang dihadapi. Penerapan Forum Rei Sitae terhadap gugatan perbuatan melawan hukum dipandang sama dengan forum rei sitae terhadap gugatan berdasarkan hubungan kontraktual karena hubungan keduanya merupakan perwujudan dari penguasaan negara atas kebendaan yang berada diwilayahnya. ${ }^{32}$

Prinsip forum rei dalam pelaksanaannya di Belanda dilakukan atas benda tetap milik tergugat sebagai klaim yurisdiksi33. Dalam ketentuan di Belanda terkait yurusdiksi memiliki ketentuan yang hampir sama dengan Amerika serikat pada Pasal 10 jo. Pasal 767 Rv Belanda mengatur bahwa apabila tergugat berada di luar wilayah Belanda namun terdapat aset milik tergugat di wilayah Belanda, maka dengan "perlekatan" aset tersebut dalam gugatan, walaupun bukan sebagai pokok perkara dari gugatan, juga dapat menimbulkan yurisdiksi bagi pengadilan Belanda untuk mengadili yang biasa disebut dengan forum arresti. Aset yang dilekatkan tersebut dapat berupa benda tetap dan benda bergerak. ${ }^{34}$

Dalam praktik di Indonesia penerapan Forum rei sitae dilekatkan pada gugatan perbuatan melawan hukum, penerapan ini banyak di temukan di beberapa kasus di Indonesia. Pengajuan gugatan berdasarkan perbuatan melanggar hukum dalam rangka melaksanakan pula gugatan yang bersifat kebendaan tidak serta merta memberikan kewenangan bagi pengadilan yang wilayah hukumnya meliputi situs benda tersebut menerapkan forum rei sitae, karena dasar gugatan yang digunakan adalah gugatan perbuatan melanggar hukum walaupun objek dari gugatan tersebut berupa benda tetap, akan tetapi gugatan tersebut tetap merupakan gugatan yang bersifat in personam.

Forum Rei sitae diperlukan ketika gugatan dilakukan untuk menghentikan kerugian akibat pelangggaran hak kebendaan, khususnya benda bergerak seperti nama domain, dalam hal gugatan diajukan dengan yurisdiksi forum rei saat maka hakim memutus berdasarkan tuntutan hak kebendaan dan ganti kerugian dan eksekusi dapat langsung dilakukan karena benda yang diajukan dalam gugatan berada dalam yurisdiksi pengadilan tersebut.

Yurisdiksi Forum rei dinilai lebih efektif untuk benda bergerak dan beberapa kasus tertentu yang membutuhkan waktu yang cepat dalam mengeksekusi putusan, karena jika Forum Rei dilekatkan pada gugatan perbuatan melawan hukum maka hakim akan lebih terfokus pada perbuatan hukum yang dilakukan oleh tergugat dan jika adanya putusan hakim maka putusan harus didaftarkan di yurisdiksi dimana benda

\footnotetext{
Bayu Seto Hardjowahono, Op it hlm.169.

Jeroen M. J. Chorus, [et.,al.], Introduction to Dutch Law, (Netherlands:Kluwer Law International 2006), hlm 276.

34 Marieke van Hooijdonk dan Peter Eijsvoogel, Litigation in the Netherlands (Netherlands:Kluwer Law International, 2012), hlm 17.
} 
berada pendaftaran putusan akan memakan waktu lebih lama, sehingga waktu eksekusi terhadap benda bergerak akan lama pula.

Amerika Serikat dalam 15 U.S.C. §1125(d) (2)(A) Anti-Cybersquatting Consumer Protection Act (ACPA) memberikan hak menggugat yang didasarkan pada prinsip yurisdiksi in rem, yang menyatakan bahwa penggugat dapat mengajukan gugatan perdata terhadap kepemilikan sebuah nama domain pada sebuah pengadilan yang memiliki yurisdiksi terhadap nama domain tersebut dikarenakan pengelola nama domain atau tempat pendaftaran nama domain tersebut berada dalam wilayah kewenangan pengadilan tersebut. Lebih lanjut diatur bahwa Pengadilan akan menerima menjalankan yurisdiksi in rem hanya apabila dipenuhi 2 (dua syarat) yaitu:

1) Nama domain tersebut melanggar hak-hak pemilik merek, dan

2) Penggugat, (a) tidak dapat menggunakan hak menggugat berdasarkan jurisdiction in personam, atau (b) tidak mengetahui keberadaan tergugat.

\section{Penutup}

Penerapan Forum in rem terhadap gugatan penggunaan nama orang terkenal sebagai nama domain oleh pihak lain yang berada di wilayah lain atau negara lain merupakan forum yang tepat karena nama domain merupakan benda bergerak tidak berwujud, penggunaan nama domain lekat dengan proses bisnis yang jika digunakan oleh pihak lain akan menimbulkan kerugian bagi orang terkenal. Penerapan yurisdiksi in rem dinilai tepat karena orang terkenal dapat mengajukan gugatan di tempat nama domain didaftar sehingga saat putusan pengadilan keluar maka pelaksanaan eksekusi dapat langsung dilakukan, selain itu Yurisdiksi in rem dinilai lebih efektif karena hakim akan memutus hanya perkara kebendaan saja, tidak terlebih dahulu memutus perkara perbuatan melawan hukum, dengan mempersingkat waktu maka kerugian akibat penggunaan nama domain dapat diminimalisir.

Sumirnya Hukum Acara dalam ranah Hukum Perdata Internasional membuat Hakim di pengadilan tempat gugatan yurisdiksi in rem diajukan ragu-ragu dalam menerima dan memutus perkara, kesumiran terjadi karena tidak adanya aturan hukum yang jelas yang menyebut bahwa yurisdiksi yang tepat untuk benda (nama domain) adalah menggunakan yurisdiksi In Rem. Kekosongan hukum terkait hukum perdata internasional ini dapat diisi dengan dibuatnya peraturan perundangundangan berupa undang-undang tentang hukum materiil dan hukum formil terkait hukum perdata internasional yang menitik beratkan pada kualifikasi hukum suatu peristiwa/perkara hukum perdata internasional.

\section{Daftar Pustaka}

\section{Buku}

Arief Sidharta, Hukum dan Logika (Essays in Legal and Moral Philosophy), (Bandung: Alumni, cetakan kedua, 2002).

Arthur T. Von Mehren, Adjudicatory Authority in Private International Law: A Comparative Study (Dordrecht Netherlands: Martinus Nijho Publishers ed, 2007).

Bayu Seto Hardjowahono, Dasar-Dasar Hukum Perdata Internasional (Bandung: Citra Aditya Bakti 2006).

Deborah E. Bouchoux, Intellectual Property (the law of trademarks, Copyrights, Patents and Trade Secrets, (New York: Delmar Cengage Learning 5 Maxwell Drive,2012)

Jeroen M. J. Chorus. et al., Introduction to Dutch Law (Netherlands: Kluwer Law International, 2006).

Mieke Komar Kantaatmadja. Et al., Cyberlaw - Suatu Pengantar (Jakarta: ELIPS II., 2002). 
Marieke van Hooijdonk dan Peter Eijsvoogel, Litigation in the Netherlands (Netherlands: Kluwer Law International, 2012).

Muhamad Djumhana, Perkembangan Doktrin dan Teori Perlindungan Hak Kekayaan Intelektual, (Bandung: PT. Citra Aditya Bakti, 2006).

M. Yahya Harahap, Segi-Segi Hukum Perjanjian (Bandung: Alumni, 1986).

Paul Scholten diterjemahkan oleh B. Arief Sidharta, Struktur Ilmu Hukum (De Structuur der Rechtswetenschap) (Bandung: Almuni, cetakan pertama, 2003).

Pedro Alberto De Miguel Asensio, The Private International Law Of Intellectual Property And of Unfair Commercial Practices: Convergence Or Divergence? S. Leible and A. Ohly eds. (Intellectual Property and Private International Law, Tübingen, Mohr Siebeck, 2009).

R. Setiawan, Pokok-Pokok Hukum Perikatan (Bandung: Binacipta, 1977).

Retnowulan Sutantio dan Iskandar Oeripkartawinata, Hukum Acara Perdata dalam Teori dan Praktek (Bandung: Mandar Maju Cetakan VIII, 1997).

Subekti, Pokok-Pokok Hukum Perdata (Jakarta: Intermasa, 2001).

Sudikno Mertokusumo, Hukum Acara Perdata Indonesia (Yogyakarta: Penerbit Liberty Cetakan Pertama, Edisi Kelima, 1998).

Trevor C. Hartley, International Commercial Litigation (Text, Cases and Materials on Private International Law (United Kingdom: Cambridge University Press, 2010).

Van Eechoud, The defendant usually resides in the same state in which it carries out its activities and is often the only state with jurisdiction di dalam Lydia Lundstedt, Territoriality in intellectual property law (Stockholm, Stockholm University:Sweden by Holmbergs, 2003).

Sudikno Mertokusumo, Penemuan Hukum: Sebuah Pengantar (Yogyakarta: Liberty, edisi pertama, 1996).

Wirjono Prodjodikoro, Perbuatan Melanggar Hukum Dipandang Dari Sudut Hukum Perdata (Bandung: Mandar Maju, 2000).

Wirjono Prodjodikoro, Asas-Asas Hukum Perjanjian, Bandung: Sumur, 1993, hlm. 13-14, dalam Rachmadi Usman, Hukum Hak Atas Kekayaan Intelektual, Perlindungan dan Dimensi Hukumnya di Indonesia, (Bandung: PT. Alumni, 2003)

\section{Makalah/Artikel/Prosiding/Hasil Penelitian}

Maria S.W tentang Metodologi Penelitian bagi Dosen Fakultas Hukum Universitas Gadjah Mada. Sumardjono, "Pedoman Pembuatan Usulan Penelitian" (makalah disampaikan pada Seminar, Yogyakarta, 12 April, 1989).

Muhamad Amirulloh,"Penggunaan Nama Kota Sebagai Nama Domain di Indonesia", Sosiohumaniora 19:1, (2017).

Muhamad Amirulloh, Rika Ratna Permata,dan helitha Novianty, Kewenangan Orang Terkenal dalam Menggugat Cybersquater berdasarkan Undang-Undang Nomor 11 Tahun 2008 Tentang Informasi dan Transaksi Elektronik dan UndangUndang Nomor 20 Tahun 2006 Tentang Merek di Indonesia, (Laporak Akhir Penelitian Unggulan Perguruan Tinggi, Agustus 2017).

Ilhami Ginang Pratinida, "Penerapan Forum Rei Sitae", yuridika Jurnal, Vol 30 (2015), https:// e-journal.unair.ac.id/index.php/YDK/index (diakses 15 Juni 2018).

The Hon Neil Brown QC, " the Arbitration of Celebrity Domain Name Dispute", 2008, https://udrp. adr.eu/_inc/en/resource/arbitration_platform/ article_en_1.pdf, (diakses 28 Mei 2018)

WIPO Arbitration and Mediation Center, "Administrative Panel Decision: Julia Viona Robert v Russel Boyd Case No.D2000-0210, 2000, http://www.wipo.int/amc/en/domains/ decisions/html/2000/d2000-0210.html, (diakses 28 mei 2018)

\section{Internet}

Toto Raharjo, Penyalahgunaan Nama Cak Nun untuk Akun Media Sosial Tidaklah Bertanggung Jawab, 28 Desember 2015, https://www. caknun.com/2015/menyalahgunakan-namacak-nun-untuk-akun-media-sosial-tidaklahbertanggungjawab/, (diakses 15 Juni 2018).

Pengelola Nama Domain Internet Indonesia, Statistic Domain 2016-2018, https://pandi.id/ en/statistic/, (diakses 15 Juni 2018). 